\title{
Relationship between Teacher Academic Qualification with Learning Management in Early Childhood
}

\author{
Tika Wulandari ${ }^{1}$
}

1PG PAUD FKIP Universitas Muhammadiyah Surakarta

\section{ABSTRACT}

Research on the Influence Motivation Study and Environmental Learning Against Achievement Learning Students showed that There is the influence of positive motivation to learn and environmental learn to achievement learn student . case is shown by the analysis of regression linear multiple, that the value of $t$ count motivation to learn at 2.476 with significance $0.016<0.05$ then $\mathrm{HO}$ is accepted, and environmental learning has value $t$ arithmetic amounted to 4.977 with significance $0.000<0.05$ then $\mathrm{HO}$ is accepted. While the value of $\mathrm{F}$ arithmetic amounted to 53.069 , and the value of $\mathrm{R}$ square of 0.639 (63.9\%). Relative contribution to the variable of learning motivation give a donation of $31 \%$ and variable environment study provides donations relatively amounted to $69 \%$, the total contribution relative of $100 \%$. Donations effective at variable motivation to learn by $19.81 \%$ and environment study by $63.91 \%$, which means that the motivation to learn and environment study are jointly provide donations effectively amounted to $63.91 \%$ against the achievement of learning, and $36.09 \%$ of other variables not examined .

\section{KEY WORDS}

quality of educational services, early childhood education

institutions, parents satisfaction level

\section{CORRESPONDING AUTHOR:}

email: tikawulandari024@gmail.com

Manuscript submitted May 21, 2020; accepted June 17, 2020.

Copyright: @2020 This is an open access article under the terms of the Creative Commons Attribution License, which permits unrestricted use, distribution, and reproduction in any medium, provided the original author and source are credited.
ECRJ (Early Chilhood Research Journal)

ISSN Numbers: Print, 2655-6448; Online, 2655-9315

\section{ADDRESS}

Website: http://journals.ums.ac.id/index.php/ecrj

Address: Pendidikan Guru PAUD

Universitas Muhammadiyah Surakarta

A. Yani Street No. 1, Pabelan, Kartasura, Surakarta, Indonesia

Telp. +62-271-717417 ext.

Email: ecrj@ums.ac.id

\section{INTRODUCTION}

Early Childhood is a child who is at the age of 0-8 years who were in the stage of growth and development, both physically and mentally. According Beichler and Snowman ( Dwi Yulianti , 2010: 7), children aged early is the child who aged between 3-6 years. Future children ages early often called the term " golden age " or the period of gold. At times it almost the entire potential of children experiencing time sensitive to grow and thrive in a fast and intense. Every child's development is not the same because every individual has a different development .

To achieve the development of optimal, children should receive education that is " decent " since early, so it appears a variety of diverse education of children aged early (ECD) with the purpose to print a generation that not only have the knowledge of qualified, but also has a personality that is good. Presence of Children Education Age Dini (ECD) continues to 
show growth that is very rapid. Developments that so it should continue to be observed and nurtured in order to clear him. Society needs to be introduced to the programs of early childhood there as well as the organization of early childhood either by the government or agencies of private or NGO. This condition also opens opportunities to improve the implementation of PAUD programs in the field of education. Education is an investment period of long and is one of the components essential for the advancement of living humans . One of the components that are in education is teachers.

Teachers here have a role that is very great that deliver the children of the nation to achieve the goals. In Law No. 14 of 2005 concerning Teachers and Lecturers article 4 indicates that teachers as learning agents function to improve the quality of national education. The statement that contained in the article that carries the consequence that " every teacher" ( without looking at where tasks ) are required to be able to channel the insight knowledge and ilmuanya kepad a student so that they Dapa $t$ grow and evolve in accordance with teak himself respectively .

To be able to carry out their duties with good then a teacher should have the insight, intellectual, personality, responsibility responsible, innovative, creative, proactive, and participatory and the spirit of self . In addition it is to achieve human resources quality required qualifications and competencies that relate to the duties and responsibilities he replied. Qualification is the expertise that is necessary to do something, or occupy positions specified. So qualifying encourage someone to have a " skill or prowess special ". With their qualifications and competence are expected to become energy educator and teacher professionalism.

In the Regulation of the Minister of Education and Culture of the Republic of Indonesia No. 137 Year 2014 is set a few things about the qualifications of academic early childhood teachers include : (a) has Diplomas four (D-IV) or Degree (S1) in the field of education of children of age early which was obtained from a program of study accredited (b) have a diploma four ( D-IV) or Bachelor (S1) education of other relevant or psychology are derived from a program of study accredited and have a certificate of Education Professional Teachers (PPG) ECD and colleges height are accredited . Efforts were made government to improve the qualifications of academic teachers are not only limited to the degree bachelor course but how the teacher is able to improve the insight , knowledge and science that are in themselves teachers, so that the horse can manage learning with good. Lessons were well implemented in a systematic and continuous . Activity learning is designed to follow the principles of learning, breadth of cargo / materials, the experience of learning, a place and time to learn, tool / source of learning , a model of learning and how to vote.

According Oemar Hamalik (2001: 57) Learning is a combination that is composed include elements of human, material, facilities , equipment, and procedures which mutually affect achieving the purpose of learning . Humans are involved in the teaching system consisting of students, teachers and other personnel, such as laboratory personnel. In 
Law No. 20 of 2003 concerning the National Education System article 1 paragraph 20 states that "Learning is the process of interaction of students with educators and learning resources in a learning environment ". Management is the process of planning, organizing, leadership and control activities of members of the organization and the use of sources of power organization other to achieve the purpose of the organization that has been designated Nature, in Fory A. Naway, (2016: 15).

Learning management is a process to achieve learning objectives. To achieve the goal of learning the necessary process of long which starts with the planning, organizing / implementation and assessment. Planning learning ECD includes planning Semester ( Prosem ), Plan of Implementation of Learning Week (RPPM), and the Plan of Implementation of the Learning Day (RPPH). Appropriate that contained in the Regulation of the Minister of Education and Culture of the Republic of Indonesia 137 Year 2014 one of them discuss about the qualification of personnel of educational institutions early childhood, that should have early childhood teachers have a background behind graduates of S1 ECD.

Based on statistical data in the UPT Education Office in Colomadu District it is known that the number of Aisyiyah Kindergarten teachers in Colomadu District there are 51 teachers spread in 11 Kindergartens. According to the Head of UPTD in Colomadu Subdistrict the qualifications of kindergarten teacher education around $70 \%$ of teachers already have PAUD S1 education and another $30 \%$ are still in the stage of attending education.
Qualifying teachers certainly influence on learning in class, both from the aspect of making the planning to the implementation of learning to assessment. It it makes the background behind the teacher is important for the continuity of the process of learning in the classroom .

In reality the field is still a lot of educators ECD or teachers who experience difficulties in the manufacture of the planning of learning, so that in the implementation of learning teachers still use Worksheet (Sheet Working Students ). The hope through the various policies that stipulated by law with all its consequences, is able to improve the performance of teachers in managing learning in the classroom. By because the researchers are interested want to do research with the title " Relationship Between Qualifications Academic Master In Management Learning In Kindergarten Aisyiyah SE District of Colomadu Year Doctrine 2018/2019".

\section{Definition of academic qualifications}

According to Law Number 14 Year 2005 article 1 paragraph 9 regarding Teachers and Lecturers uses the term academic qualifications, which are defined as academic education diplomas which must be owned by the teacher or lecturer according to the type, level, and formal education unit at the assignment place. In Government Regulation No. 19/2005 article 28 paragraph 2, academic qualifications as a minimum level of education must be fulfilled by an educator as evidenced by a relevant diploma or certificate of expertise in accordance with applicable laws and regulations. Based on the above understanding 
it can be concluded that academic qualifications encourage teachers to have expertise in the world of education as a prerequisite for serving in a particular position especially teachers.

\section{Understanding Learning Management}

Management is the process of planning, organizing, leadership and controlling the activities of members of the organization and the process of using other organizational resources to achieve organizational goals set by Nature, in Fory A. Naway, ( 2016: 15). According to Suprianto and Muhsin, in Fory A. Naway, (2016: 15) management is the skill to mix the components and elements involved in a system to achieve the results or goals that are planned.

Learning is a combination that is composed, including human elements, material, facilities, equipment, and procedures, which influence each other to achieve learning objectives (Hamalik, Oemar 2001: 57). According to Dimyati and Mudjiono, in Syaiful Sagala (2006: 62) learning is the teacher's activities programmed in instructional design, to make students learn actively, which emphasizes the process of providing learning resources.

Based on the above opinion it can be concluded that the management of learning is a comprehensive learning process that aims to achieve educational goals as previously planned.

\section{The Role of Teacher Academic Qualifications with Learning Management}

In the Regulation of the Minister of Education and Culture of the Republic of Indonesia No.
137 of 2014 stipulates a number of things about PAUD teacher academic qualifications including: (a) having a Diploma four (D-IV) or Bachelor (S1) in the field of early childhood education obtained from an accredited study program (b) having a four diploma diploma ( DIV) or Bachelor (S1) other relevant education or psychology obtained from an accredited study program and has a certificate of Teacher Professional Education (PPG) PAUD and an accredited tertiary institution.

In addition to having an academic qualification, a teacher must also have some competence. There are 4 competencies as listed in Government Regulation No. 19 of 2005 article 28 paragraph 3, concerning the National Standards of Education, namely, pedagogical, personal, professional and social competence. The competence refers to the activities of the teacher in the learning process namely how to plan learning, carry out learning, and assess learning outcomes. Competence refers to performance and deeds and to meet these specifications required academic qualifications in accordance with their respective fields of work, so it can be concluded that the higher the academic qualifications of teachers, the better the teacher's performance in managing learning.

\section{RESEARCH METHOD}

Methods of research are used in research this is a method of quantitatively with the type of research descriptive correlational . According to Siregar (2013: 8) research descriptive is research that has the procedure solving a problem with the way describe the 
object of research on the current state of the current based on the facts as the existence, then analyzed and interpreted its shape in the form of surveys and studies developments . According Sugiyono (2014: 87) analysis of the relationship (correlation) is an analysis that is trying to connect the dots between one element / elements other to create the shape and form of the new that is different from the previous . Correlational descriptive research seeks to describe the relationship or interrelationship of several variables by describing the results of the study. Before you do the analysis of the data, especially previously performed testing of prerequisite analysis by using the analysis of test normaliitas and test linearity . Having done the testing requirements analysis, can be done testing the hypothesis by using test regression linear simple.

The population of the research is that the kindergarten teacher Aisyiyah all the District Colomadu with the number of 51 teachers consisting of 15 teachers and 36 teacher WB civil servants. While researchers determined the sample based on the Yamene sample formula, so a sample of 34 teachers was obtained. In this study a sampling technique was carried out to reflect the balance of the study population. Mechanical taking samples or technique of sampling in a study it is proportional random sampling. Proportional because it takes into consideration consideration in sub- populations. Random ie taking samples in random in each subpopulation and number of each character of the population .
In this study the data collection techniques used were questionnaires and documentation . In a study of this, research in ti use a type of cake sioner closed ie with questions that are already provided the answer, so that the respondent lived choose an answer by giving marks checklist . Researchers used questionnaires to obtain data on teacher academic qualifications and management of learning. Sources of data in the study is that the source of primary data obtained through the deployment of a questionnaire. While the researchers took the data through documents and notes about the report data on the number of Aisyiyah Kindergarten teachers in Colomadu District in November from the UPT of the Colomadu District Education Office .

\section{RESULTS AND DISCUSSION}

Data variable qualified academic teachers was obtained through a questionnaire variables qualified academic with 15 grains of questions and the number of respondents as many as 34 teachers. Obtained the highest number of scores of 75 and the lowest number of scores of 58 . The results of the analysis showed an average ( mean ) of 63.79, a median of 61.00 , mode 60 , a standard deviation of 5.871 and a range of 17 .

While the data variable management of the learning obtained through questionnaires variable management of learning with 15 grains of questions and the number of respondents as many as 34 teachers. Retrieved number of scores the highest at 75 and the number of scores the lowest at 52 . The results of the analysis showed the average ( mean ) of 
$63.32,61.50$ median, mode 60 , the standard deviation of 6,094 and a range of 24 .

Before doing the analysis of the data, especially in advance do test prerequisite analysis . In this study using the normality test and linearity test as a prerequisite for simple linear regression analysis. Obtained from the results of output management of learning has a value sig. 0.018> 0.05, then the data is normally distributed. Obtained from the results of the output qualifications of academic teachers have value sig. $0.038>0.05$, then the data is normally distributed . Obtained from the results of output above the value $F$ arithmetic $=1.806 \mathrm{~F}$ table $=$ obtained from table values criticism distribution $\mathrm{F}$ by way of notice $\mathrm{df} / \mathrm{db} 2=23$ ( seen from within groups), so that $\mathrm{F}$ table $=2.32, \mathrm{~F}$ arithmetic $=1.806<\mathrm{F}$ table $=2.32$ and the value of sig. $0.122>0.05$, it is said that the relationship between the variables of teacher academic qualifications $(X)$ and the learning management variable $(Y)$ is linear.

Having done the test requirements analysis , then can do the calculations to test the hypothesis using the test regression linear simple. Based on the comparison results obtained by the correlation coefficient ( rxy ) of 0.909 , meaning that it is very strong. The correlation sign is + ( positive ) meaning that if the teacher's academic qualification scores increase, the management of learning also increases and vice versa. Teacher academic qualifications with learning management have Sig. $0,000<0.05$, then $\mathrm{HO}$ is rejected and $\mathrm{Ha}$ is accepted. Decision, there is a correlation or relationship between the academic qualifications of teachers with the management of learning. So it can be taken a decision that, there is a correlation or relationship between the academic qualifications of teachers with the management of learning in Aisyiyah Kindergarten in Colomadu District 2018/2019 school year".

In the analysis of regression linear simple unknown magnitude value of the correlation or relationship (R) which amounted to 0.909 and explain the magnitude of the percentage of the effect of variable -free against variable dependent who called the coefficient of determination which is the result of pen gkuadratan R. D ari output of the obtained coefficient of determination ( $R 2$ ) of 0.826 , which contains the notion that the effect of variable -free (qualified academic teachers) against variable dependent ( managing learning ) is at $82.6 \%$, while the remainder is $17.4 \%$, influenced by variables other . Regression equation $Y=3.135+0.943 X$. The constant of 3.135 states that if it did not exist the value of qualifications academic then the value of management at 3,135 . The coefficient of regression of $X 1$ amounted to 0.943 states that each additional 1 value of qualifications academic, it will increase the value of the management of learning at 0.943 .

Qualification is a skill that is required to do something, or occupy positions specified. Qualifications encourage someone to have a " skill or prowess special ". Improving academic qualifications is very important because it is an influential thing to achieve success in managing learning that is equal to $82.6 \%$. So the hypothesis that there is a positive relationship on the teacher's academic 
qualifications with learning management can be accepted. Tested the hypothesis above is supported by research that is carried out by by Heni Sugini (2011) in kindergarten all the District Paguyangan, that there is a relationship that is very significant between the qualifications of academic teachers with a pattern of management student . Research that is conducted by Sri Lestari (2015/2016) in kindergarten all the District Gemolong, that there is a relationship that is very strong between the qualifications of academic teachers with management classes .

\section{CONCLUSION}

Based on data analysis and discussion that has been done, it can be concluded from this study that there is a positive relationship between teacher academic qualifications and learning management of 0.909 . This means that if the academic qualifications of teachers increase, the management of learning in Aisyiyah Kindergarten in Colomadu District will also increase and vice versa . Qualifications of academic teachers and management pe mbelajaran has a value Sig. $0,000<0.05$, then $\mathrm{HO}$ is rejected and $\mathrm{Ha}$ is accepted. So $\mathrm{d}$ apat taken the decision that, there is a correlation or relationship between the qualifications of academic teachers with the management of learning in kindergarten Aisyiyah all the District Colomadu the teachings 2018/2019 ".

\section{REFERENCES}

Hamalik, Oemar. 2001. Kurikulum dan pembelajaran. Jakarta: bumi aksara
Peraturan Menteri Pendidikan dan Kebudayaan Republik Indonesia No. 137 Tahun

2014 tentang Standar Nasional Pendidikan Anak Usia Dini

Siregar, Syofian. 2013. Metode Penelitian Kuantitatif Dilengkapi Dengan

Perbandingan Perhitungan Manual dan SPSS. Jakarta: Kencana Prenada Media Group.

Sugiyono. 2014. Metode Penelitian Kuantitatif Kualitatif Dan R \& D. Bandung: Alfabeta

Undang-Undang Nomor 14 Tahun 2005 tentang Guru dan Dosen

Undang-Undang Nomor 20 Tahun 2003 tentang Sistem Pendidikan Nasional 